\title{
Infiltration and water retention of biological soil crusts on reclaimed soils of former open-cast lignite mining sites in Brandenburg, north-east Germany
}

\author{
Stella Gypser ${ }^{1 *}$, Maik Veste ${ }^{1,2}$, Thomas Fischer ${ }^{3}$, Philipp Lange ${ }^{4}$ \\ ${ }^{1}$ Brandenburg University of Technology Cottbus-Senftenberg, Chair of Soil Protection and Recultivation, Konrad-Wachsmann-Allee 6, \\ 03046 Cottbus, Germany. \\ ${ }^{2}$ University of Hohenheim, Institute of Botany - Experimental Ecology, Garbenstrasse 30, 70599 Stuttgart, Germany. \\ ${ }^{3}$ Brandenburg University of Technology Cottbus-Senftenberg, Central Analytical Laboratory, Konrad-Wachsmann-Allee 6, \\ 03046 Cottbus, Germany. \\ ${ }^{4}$ Dresden University of Technology, Department of Chemistry and Food Chemistry, Mommsenstraße 4, 01062 Dresden, Germany. \\ ${ }^{*}$ Corresponding author. Tel.: +49 0355/69 3318. Fax: +49 0355/69 2323. E-mail: stella.gypser@b-tu.de
}

\begin{abstract}
Investigations were done on two former open-cast lignite mining sites under reclamation, an artificial sand dune in Welzow Süd, and a forest plantation in Schlabendorf Süd (Brandenburg, Germany). The aim was to associate the topsoil hydrological characteristics of green algae dominated as well as moss and soil lichen dominated biological soil crusts during crustal succession with their water retention and the repellency index on sandy soils under temperate climate and different reliefs.

The investigation of the repellency index showed on the one hand an increase due to the cross-linking of sand particles by green algae which resulted in clogging of pores. On the other hand, the occurrence of moss plants led to a decrease of the repellency index due to absorption caused by bryophytes. The determination of the water retention curves showed an increase of the water holding capacity, especially in conjunction with the growth of green algae layer. The pore-related van Genuchten parameter indicate a clay-like behaviour of the developed soil crusts. Because of the inhomogeneous distribution of lichens and mosses as well as the varying thickness of green algae layers, the water retention differed between the study sites and between samples of similar developmental stages. However, similar tendencies of water retention and water repellency related to the soil crust formation were observed.

Biological soil crusts should be considered after disturbances in the context of reclamation measures, because the initial development of green algae biocrusts lead to an increasing repellency index, while the occurrence of mosses and a gain in organic matter enhance the water holding capacity. Thus, the succession of biocrusts and their small-scale succession promote the development of soil and ecosystem.
\end{abstract}

Keywords: Repellency index; pF-curves; Water holding capacity; Biological soil crusts.

\section{INTRODUCTION}

Soils play a major role for biogeochemical and hydrological cycles in ecosystems worldwide. They have influence on nutrient and organic matter dynamics, water distribution, plant growth as well as biodiversity (e.g. Belnap, 2006; Bradshaw, 1997; Brevik et al., 2015; Büdel, 2003; Elliott, 1985; Housman et al., 2006; Lambers et al., 2008; Passioura, 1991). The onetime process of surface mining is a human temporary impact, but drastically affects the landscape structure and natural ecosystem services and functioning worldwide (Krümmelbein et al., 2012; Walker and Willig, 1999). While in the early $20^{\text {th }}$ century underground mining dominated, the mine production shifted and open pit mining techniques became more common. In 2010, open pit mining was the major industrial mine operation worldwide, and played a major role e.g. in the United States of America, Canada, Australia, China, Russia, South Africa and Brazil (ICMM, 2012). In Central Europe, especially in Poland, the Czech Republic and Germany belong to the world's largest lignite producers. In Germany the three main mining areas are Rhineland, Central Germany and Lusatia with an annual production of 185 million tons of lignite (Statistik der Kohlewirtschaft e.V., 2013). The latter is one of the largest mining areas in Germany (Krümmelbein et al., 2012), and postmining landscapes of the Lusatian mining district cover an area of approximately $800 \mathrm{~km}^{2}$ (Hüttl, 1998).
Human disturbances during mining activities can strongly affect these ecosystem properties by destruction of naturally developed soils and removal of vegetation. As a result, a mixture of quaternary and tertiary sandy and unstructured material, excavated from great depths during the mining process, is the basic substrate for soil development in reclaimed areas (Gerwin et al., 2009; Krümmelbein et al., 2012). This leads to special characteristics of soils developing on mine spoils, which are different from naturally developed soils (Schaaf and Hüttl, 2005; Šourková et al., 2005). The different geological origins of these sediments result in small-scale heterogeneity of chemical and physical soil properties (Hangen et al., 2005). Among characteristics like a low $\mathrm{pH}$, increased solubility of toxic metals as well as low levels of nutrients such as nitrogen, phosphorus or potassium were obtained, as well as very coarse or very fine texture of the substrate were obtained. Especially the substrates containing little amounts of organic matter lead to high bulk densities, compaction, low water infiltration rates, reduced water holding capacities and, hence, higher susceptibility to wind and water erosion (Bradshaw, 1997; Cooke, 1999; Krümmelbein et al., 2010; Nordstrom and Alpers, 1999; Reuter, 1997; Roberts et al., 1988).

Reclamation measures can promote the establishment of stable and self-sustaining ecosystems, first steps being represented by the physical stabilization of the terrain as well as the restoring of the topsoil (Dutta et al., 2005). For the promotion of colonization by plants, restoration activities like mulching, 
direct or hydraulic seeding or nurse plants are used (Cooke, 1999), while extreme soil conditions can prevent plant growth (Bradshaw, 1997). Hence, in the initial stage of the ecosystem development, the post-mining sites are open areas without or with a low cover of higher vegetation (Wiegleb and Felinks, 2001). In this context, first cryptogamic pioneers, which are able to colonize the soil surface under such extreme conditions without human support, played a key role in the soil development and niche formation for higher plants (Bowker et al., 2014; Cutler et al., 2008). Therefore, green algae, cyanobacteria and bacteria (Veste, 2005) promoted cross-linking of mineral particles, form biological soil crusts and accumulate organic biomass (Büdel, 2003; Dümig et al., 2014). Stewart and Siciliano (2015) showed that the advantages of biocrusts could be implemented early in systematic reclamation measures, if mature biocrusts were applied as slurries on disturbed areas. While the natural growth of biological soil crusts took several years, these biocrusts slurries established within a few months.

Meanwhile, it is a well-known fact from studies in arid and semi-arid regions, that different biological soil crusts influence soil hydrological processes (Belnap, 2006). They modify the water run-off infiltration balance (Kidron and Yair, 1997) and alter water re-distribution on different scales (Eldridge et al., 2002; Kidron, 2014). Increased porosity, enhanced aggregate stability and an improved physical structure have been reported to cause higher infiltration (Mager and Thomas, 2011; Menon et al., 2011; Rossi et al., 2012), while water repellency and clogging of pores led to a reduced infiltration (Kidron et al., 1999; Malam Issa et al., 2009). Also an influence of soil crusts on infiltration can be masked by soil properties like structure or texture. Williams et al. (1999) reported no significant effect of cyanobacteria-dominated crusts on hydrological properties of a sandy loam soil, but did not exclude an influence with continuing crustal development, and thus, changing species composition or crustal organic matter accumulation.

Comprehensive studies that were carried out in the arid dune systems of the Northern Negev demonstrated that the species composition had drastic effects on infiltration, run-off processes and on the soil moisture content below the biocrusts (Kidron and Yair, 1997; Kidron et al., 2003). Biological soil crusts could improve the soil water availability in the top soil with increased rainfall, while increased coverage by mosses and soil lichens limited rainwater infiltration under higher rainfall amounts (Yair et al., 2008, 2011). Cyanobacterial crusts enhanced run-off along the dune slope, affecting vegetation development and ecosystem processes (Breckle et al., 2008; Veste et al., 2011). These studies emphasized the importance of the species composition of biocrusts (e.g. Breckle et al., 2008; Kidron and Yair, 1997; Kidron et al., 2003; Yair et al. 2011).

Extreme habitats like sand dunes also occured in the temperate zone of Europe, where soil surfaces were covered with biological soil crusts (Büdel, 2003). Only a few hydrological studies were conducted on sandy soils (Fischer et al., 2010; Lichner et al., 2013) and in reclaimed areas (Dümig et al., 2013; 2014; Fischer et al., 2013; Spröte, 2013; Spröte et al., 2010). Fischer et al. (2010) investigated biological soil crusts on inland dunes deposited during the last glacial period in southern Brandenburg (NE Germany) regarding their hydrological characteristics. Here, the soil crusts were of an early successional stage and built up by Zygogonium ericetorum, Klebsormidium crenulatum and Polytrichum piliferum (Fischer et al., 2013).

To examine, whether the influence of crustal species composition influences the hydrological behaviour and the repellency index of biological soil crusts compared to pure mining substrate without incrustation, the present study was conducted on two former lignite open-cast mining sites: an artificial sand dune on the reclaimed watershed Welzow Süd "Neuer Lugteich" and a reforestation area in Schlabendorf Süd. Different successional stages of soil crusts were identified from initial and more developed soil crusts as well as final moss-lichen crusts, forming a small-scale crust pattern (Gypser et al., 2015). Therefore, the aim of this study was to relate the hydrological characteristics of the topsoil to successional stages of biological soil crusts on reclaimed soils and their influence on repellency index and water holding capacity. In addition, both the effect of biological soil crusts on sandy soils of temperate climate and the different geomorphological formation of the reclaimed sites were included. In comparison to previous studies that were carried out mainly in arid and semiarid regions, the influence of green algae crusts without any cyanobacteria on the repellent behaviour of the biological soil crusts was proved.

\section{METHODS \\ Study sites}

The sampling of biological soil crusts took place on the reclamation areas Welzow Süd and Schlabendorf Süd in March 2014. Both sites are located in the Lusatian open-cast lignite mining district in the vicinity of Cottbus (Brandenburg, Germany) (Gypser et al., 2015), which is characterized by transitional Atlantic to continental climate with a mean annual temperature of $9.3^{\circ} \mathrm{C}$ and a mean annual precipitation of $581 \mathrm{~mm} \mathrm{a}^{-1}(1981$ to 2010; DWD 2014). The first study site, a reclaimed forest plantation (RFP) on the post-mining landscape of Schlabendorf Süd (51 $\left.{ }^{\circ} 46^{\prime} 7.07^{\prime \prime} \mathrm{N}, 13^{\circ} 44^{\prime} 27.70^{\prime \prime} \mathrm{E}\right)$, is situated $40 \mathrm{~km}$ west of Cottbus and is under reclamation since 1991 (Fig. 1a). The entire area included 3269 ha and is presently used for forestry. The dumping site studied consisted of $80 \%$ tertiary and $20 \%$ quaternary material, and was characterized by a plantation of Betula pendula and scattered Pinus sylvestris (Fig. 1a). The subjacent substrate of the biological soil crusts is dominated by a medium sand and consists of $98.3 \%$ coarse to fine sand, as well as $1.7 \%$ silt and clay, respectively (Spröte, 2013). The $\mathrm{pH}$ of the sandy substrate ranged from 4.9 to 5.7 (Gypser et al., 2015), and the total carbon as well as the nitrogen content amounted to 0.3 and $0.02 \%$ in the pure substrate, respectively. The second study site, an artificial sand dune (ASD) on the restored watershed "Neuer Lugteich" $\left(51^{\circ} 35^{\prime} 53.00^{\prime \prime} \mathrm{N}\right.$, $14^{\circ} 17^{\prime} 23.20^{\prime \prime} \mathrm{E}$ ), is part of the lignite open-cast mining Welzow Süd, was constructed in 2001 and covers an area of about 4.3 ha. The overburden substrates of the sand dune are $2 \mathrm{~m}$ quaternary sands, deposited on a 1 to $2 \mathrm{~m}$ ponding clay layer without further amelioration measures (e.g. liming, fertilizing), and the characteristic plant species of the sampling plots on ASD are Corynephorus canescens and conifer trees of Pinus sylvestris (Fig. 1b). The subjacent substrate of the biological soil crust is also dominated by a medium sand and consists of $98.2 \%$ coarse to fine sand, as well as $1.8 \%$ silt and clay, respectively (Spröte, 2013). The $\mathrm{pH}$ of the sandy substrate ranged from 5.1 to 5.6 (Gypser et al., 2015), and the total carbon as well as the nitrogen content amounted to 0.1 and $0.01 \%$ in the pure substrate, respectively.

\section{Sampling strategy}

The sampling plots were selected randomly with the objective of representing mixed sites dominated by green algae, mosses, lichens, and by visually observable surface properties (colour, crust thickness, roughness and cover ratio) (Büdel and Veste, 2008; Gypser et al., 2015; Kidron and Yair, 1997). 
Infiltration and water retention of biological soil crusts on reclaimed soils
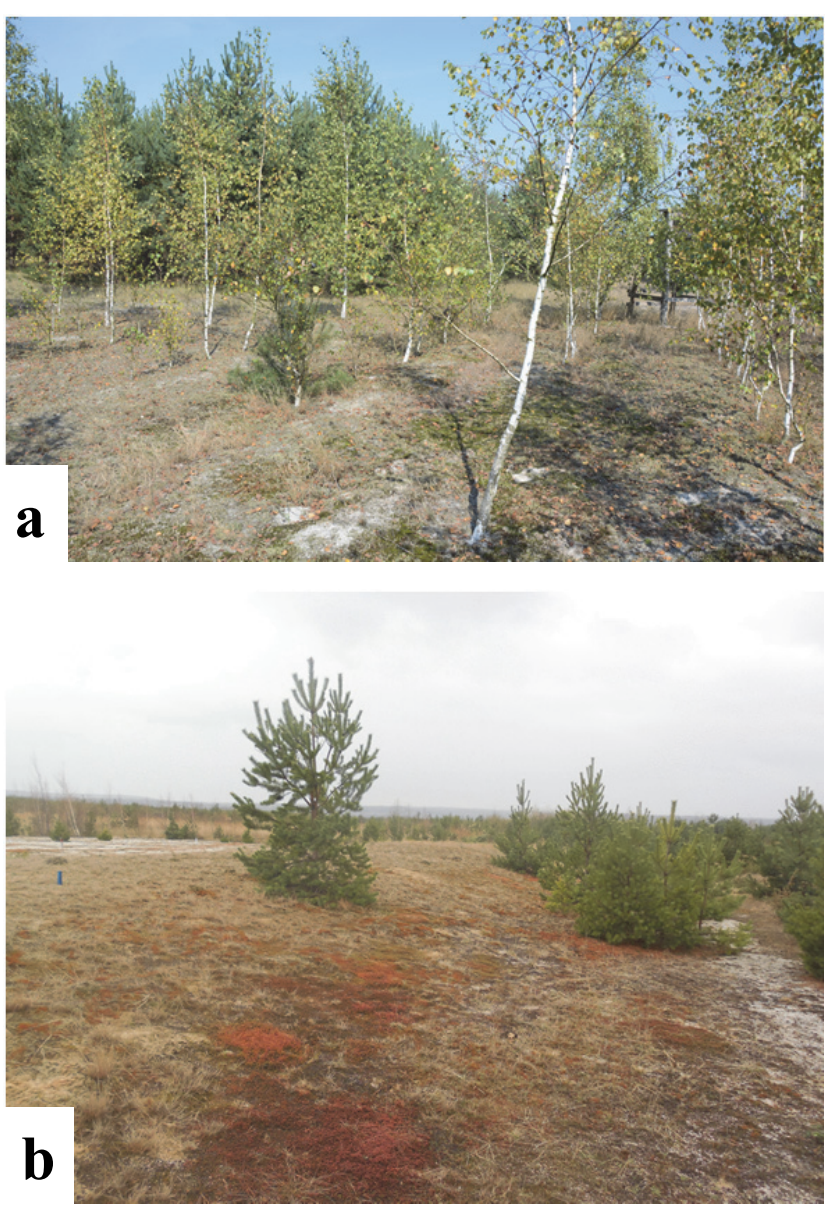

Fig. 1. Study sites: a) Overview of the reclaimed forest plantation (RFP) Schlabendorf Süd (photo September 2014); b) Overview of the artificial sand dune (ASD) Welzow Süd (photo March 2014).

For the in situ hydrological measurements, undisturbed soil crusts were collected by gently coring Petri dishes (diameter $55 \mathrm{~mm}$, depth $1 \mathrm{~cm}$ ) in the upper soil layer in order to obtain a well-defined and comparable surface area, and to avoid rupture of the crusts. Subsequently, the Petri dishes were sealed and the crusts carefully transported without harming them. In addition to the crust samples, also pure substrate samples without phototrophic organisms were taken for comparative analyses. The species composition of sampled biological soil crusts was further analysed both in the field and the laboratory.

Four (Schlabendorf as RFP: RFP 1 to RFP 4) and six (Welzow as ASD: ASD 1 to ASD 6) developmental stages, from initial to final successional stage, i.e. moss-lichen crust (e.g. ASD 6), were distinguished. On RFP, the diameters of the crust patches ranged from 10 to $30 \mathrm{~cm}$, and the crust samples RFP 1 to 3 were collected randomly on an area of about $4 \mathrm{~m}^{2}$, while RFP 4 was collected in a Betula planting approximately $9 \mathrm{~m}$ away. On ASD, the diameters of the crust patches ranged from 20 to $150 \mathrm{~cm}$, and the samples were collected randomly from culmination (ASD 1) to depth range (ASD 5) of the sand dune, while ASD 6 was sampled about 25 to $30 \mathrm{~m}$ below the dune.

The different number of crustal development stages resulted from heterogeneity in terms of species formation and surface coverage at both sites and a detailed species list can be found in Gypser et al. (2015). Per crustal development stage (RFP 1 to RFP 3, ASD 1 to ASD 5), four sub-samples were collected. From the final moss-lichen crusts (RFP 4, ASD 6), three subsamples were taken.

\section{Chemical analysis}

The total carbon content of air-dry soil crusts was determined with a CNS elemental analyser (Vario MICRO Cube, Elementar Analysensysteme $\mathrm{GmbH}$, Hanau, Germany), assuming that the total carbon content of samples reflects organic carbon. Two representative soil crust sub-samples of each crustal development stage were selected for chemical analysis on both study sites.

\section{Repellency index}

For characterizing the wetting characteristics of biological soil crusts, the ethanol-water method at a pressure-head of $-2 \mathrm{hPa}$ was used (Hallet and Young, 1999). In comparison to the water drop penetration test (WDPT), the determination of the repellency index $\left(R_{i}\right)$ is more a measurement of crust surface polarity during wetting than for hydrophobicity. While the WDPT supposed high water repellency, the $R_{i}$ involves ethanol and water flows $\left(Q_{\text {Ethanol }}\right.$ and $\left.Q_{\text {Water }}\right)$ in the biological soil crust and the subjacent substrate (Fischer et al., 2010). Hence, a possible repellent behaviour of the soil crusts was detected and the infiltration via steady state water flow was measured simultaneously. The $R_{i}$ was calculated according to Hartmann (2008), with the rearranged Equation (1) according to Fischer et al. (2010):

$$
R_{i}=1.95 \cdot \sqrt{\frac{Q_{\text {Ethanol }}}{Q_{\text {Water }}}}
$$

The steady state water flow $\left(Q_{\text {Water }}\right)$ was used to describe the infiltration rate of the undisturbed samples. Moss-lichen crusts as final stages of soil crust development were not included in the micro-infiltration measurement, because fruticose lichens already exhibited strong growth in height and broke through the mineral soil layer. Hence, they were not suitable for the measurement. For the determination of the repellency index, ten repetitive measurements with ethanol and water per crustal developmental stage were considered.

\section{Matric potential and water content}

The water retention-curves of the undisturbed crust samples including their directly subjacent substrate were determined in a sand box $(\leq 100 \mathrm{hPa})$ and a kaolin box $(100-200 \mathrm{hPa}$, Eijkelkamp, the Netherlands). The nls-function of the R software suite was used to perform a numerical fit of the van Genuchten equation to the experimental data. Furthermore, the samples were dried at $20^{\circ} \mathrm{C}$ and at a relative humidity of $65 \%$ (corresponding to $-58 \mathrm{MPa}$, van Genuchten residual water content $\Theta_{r}$ ) and at $60^{\circ} \mathrm{C}$ to constant weight (absolute dryness). For the determination of matric potential and water content, two representative soil crust sub-samples of each crustal development stage on both study sites were selected.

The statistical analysis was performed using SPSS. The Mann-Whitney-U-test was chosen for testing variances between both study sites, and the Kruskal-Wallis-test analysed differences between crustal succession stages. Differences were significant at a 0.05 -level. The Spearman-Rho was chosen to test significance of correlation. Differences were significant at a 0.01-level. 

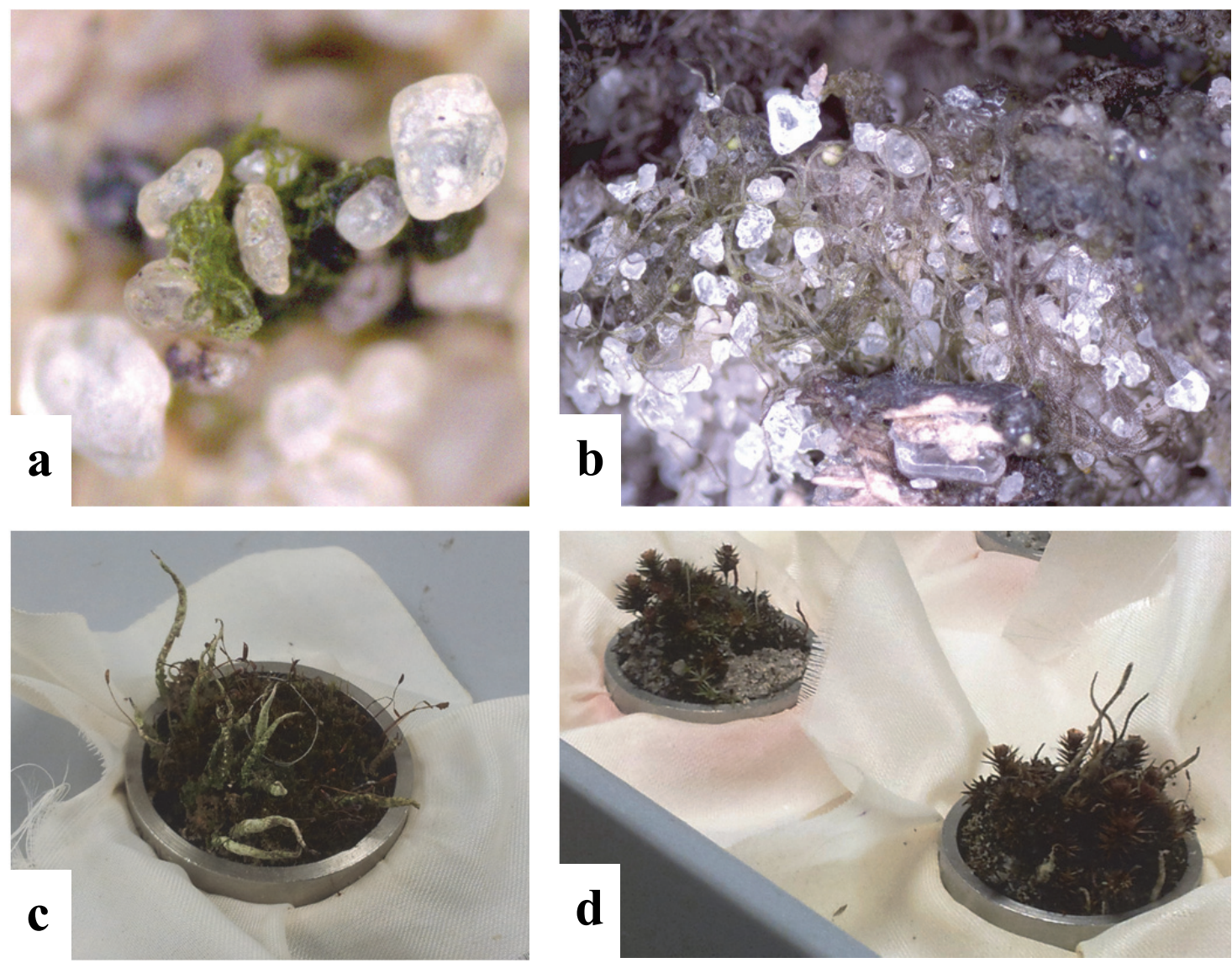

Fig. 2. Cross-linked sand particles and clogged pores by green algae filaments of Zygogonium spec. in: a) an initial biological soil crust ASD 1 from the study site Welzow and; b) a more mature crust RFP 3 from the study site Schlabendorf. Core cutter with moss and lichens as the final stage of crustal development on the study site: c) ASD 6 and; d) RFP 4.

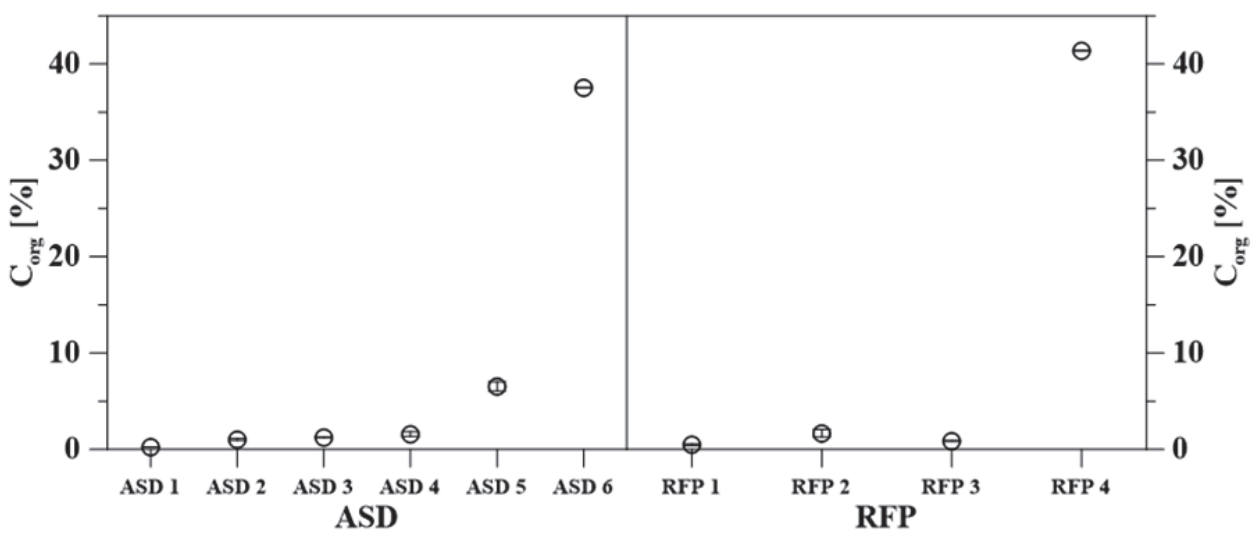

Fig. 3. Contents of organic carbon $\left(\mathrm{C}_{\text {org }}\right)$ at progressing developmental stages of biological soil crusts at the study sites ASD and RFP, mean \pm standard deviation $(n=2)$.

\section{RESULTS}

\section{Crust organic matter}

Scattered and crusted green algae layer in small patches represented the initial stage of soil crust succession (Fig. 2a and b). During soil crust succession, scattered green algae layer grew first to smooth, and later rough dense algae crusts. Moss plants and soil lichens appeared in advanced developmental stages, until final moss-lichens crusts without green algae were observed (Fig. 2c and d). During this soil crust development, biomass was progressively built-up and, hence, the contents of organic carbon increased (Fig. 3). On ASD, organic carbon of the initial $(0.3 \% \pm 0.0)$ and moss-lichen crusts $(37.5 \% \pm 0.0)$ had lower values compared to initial and mature soil crusts collected on RFP $(0.5 \% \pm 0.1$ and $41.4 \% \pm 0.0$, respectively $)$.

Comparing the organic carbon contents of the biological soil crusts between the biocrusts stages as a measure for their development using the non-parametric Kruskal-Wallis H-test, the P-values amounted to 0.081 for ASD and to 0.128 for RFP. This insignificant relation supports the hypothesis of a transient state of biological soil crusts during their succession. 


\section{Repellency index}

At both study sites, the mean repellency index $R_{i}$ was lowest in the initial soil crusts with $2.90 \pm 0.33$ in Welzow and $2.15 \pm$ 0.15 in RFP, and increased during the different stages of crust development (Fig. 4a and b). The highest $R_{i}$ was obtained ASD 3 and RFP 3 and amounted to $3.71 \pm 0.34$ and $2.79 \pm 0.64$ on ASD and RFP, respectively. During crust development, the $\mathrm{R}_{\mathrm{i}}$ obtained on ASD were altogether higher than on RFP $(\mathrm{P}<0.05)$. The mean $R_{i}$ of the RFP samples were significantly lower $(23.9 \%)$. The steady state water flow $Q_{\text {Water }}$ decreased with crustal development and was highest in the pure substrate samples with $1.00 \mathrm{mg} \mathrm{s}^{-1} \pm 0.08$ on ASD and $1.63 \mathrm{mg} \mathrm{s}^{-1} \pm 0.40$ on RFP, respectively (Fig. 4c and d). The mean infiltration rate obtained in the biological soil crusts on ASD was higher $(27.1 \%)$ than on RFP. Filaments of Zygogonium spec. were tested regarding the excretion of extracellular polymeric substance (EPS) using light and polarizing microscopy (Fig. 5). While $R_{i}$ measurements took about $75 \mathrm{sec}$, these observations took about 5 min to detect and influence of swelling EPS on $R_{i}$, but no EPS were observed.

The correlation analysis of $R_{i}$ and organic carbon contents of the various crust samples from both sites indicated that both parameters were not correlated (Fig. 6). While on RFP both initial and fully developed crust samples were located at low values of correlation, on ASD the value of the fully developed moss-lichen crust ASD 6 showed a higher carbon content without increased $R_{i}$.

\section{Soil water retention and water holding capacity}

The soil water retention curves and the respective van Genuchten parameters were presented in Fig. 7 and in Table 1, respectively. The saturated water content $\Theta_{s}$ increased with biocrust development and correlated with organic carbon (Fig. 8) (Spearman correlation coefficient $R=0.79, \mathrm{P}<0.01$ ). In turn, the van Genuchten measure of the pore-size distribution $n$ amounted to $2.66 \pm 0.21$ and to $2.23 \pm 0.12$ for the substrate

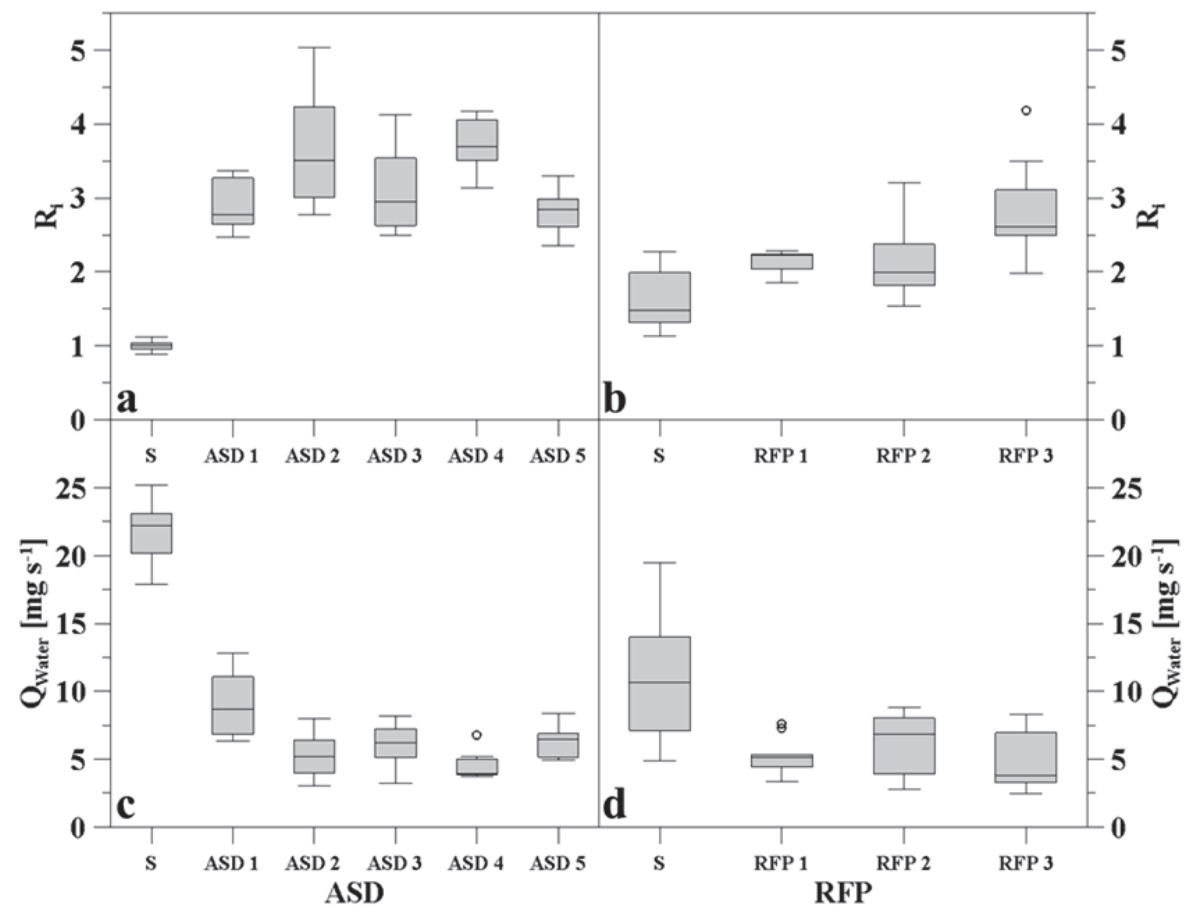

Fig. 4. Repellency index $\left(R_{i}\right)$ and steady state water flow $\left(Q_{\text {Water }}\right)$ of the biological soil crust samples at different developmental stages on the study sites ASD and RFP $(n=10, \mathrm{~S}=$ substrate).

Tab. 1. Van Genuchten parameters of the water retention functions on the sites ASD and RFP.

\begin{tabular}{lcccc}
\hline & $\Theta_{s}$ & $\Theta_{r}$ & $\alpha$ & $n$ \\
\hline ASD S & $0.526 \pm 0.013$ & $0.005 \pm 0.015$ & $0.037 \pm 0.003$ & $2.66 \pm 0.21$ \\
ASD 1 & $0.557 \pm 0.011$ & $0.006 \pm 0.010$ & $0.066 \pm 0.005$ & $2.10 \pm 0.07$ \\
ASD 2 & $0.528 \pm 0.014$ & $0.005 \pm 0.017$ & $0.044 \pm 0.006$ & $2.14 \pm 0.13$ \\
ASD 3 & $0.585 \pm 0.013$ & $0.006 \pm 0.015$ & $0.056 \pm 0.007$ & $1.86 \pm 0.07$ \\
ASD 4 & $0.535 \pm 0.013$ & $0.006 \pm 0.016$ & $0.050 \pm 0.007$ & $1.87 \pm 0.08$ \\
ASD 5 & $0.810 \pm 0.028$ & $0.010 \pm 0.044$ & $0.067 \pm 0.017$ & $1.54 \pm 0.07$ \\
ASD 6 & $1.070 \pm 0.088$ & $0.013 \pm 0.033$ & $0.353 \pm 0.133$ & $1.46 \pm 0.04$ \\
RFP S & $0.497 \pm 0.012$ & $0.003 \pm 0.012$ & $0.052 \pm 0.005$ & $2.23 \pm 0.12$ \\
RFP 1 & $0.489 \pm 0.014$ & $0.004 \pm 0.015$ & $0.054 \pm 0.007$ & $2.01 \pm 0.11$ \\
RFP 2 & $0.572 \pm 0.019$ & $0.004 \pm 0.024$ & $0.044 \pm 0.008$ & $1.93 \pm 0.13$ \\
RFP 3 & $0.517 \pm 0.019$ & $0.004 \pm 0.023$ & $0.052 \pm 0.010$ & $1.87 \pm 0.12$ \\
RFP 4 & $0.764 \pm 0.027$ & $0.007 \pm 0.024$ & $0.131 \pm 0.026$ & $1.57 \pm 0.05$ \\
\hline S $=$ substrate & & & &
\end{tabular}



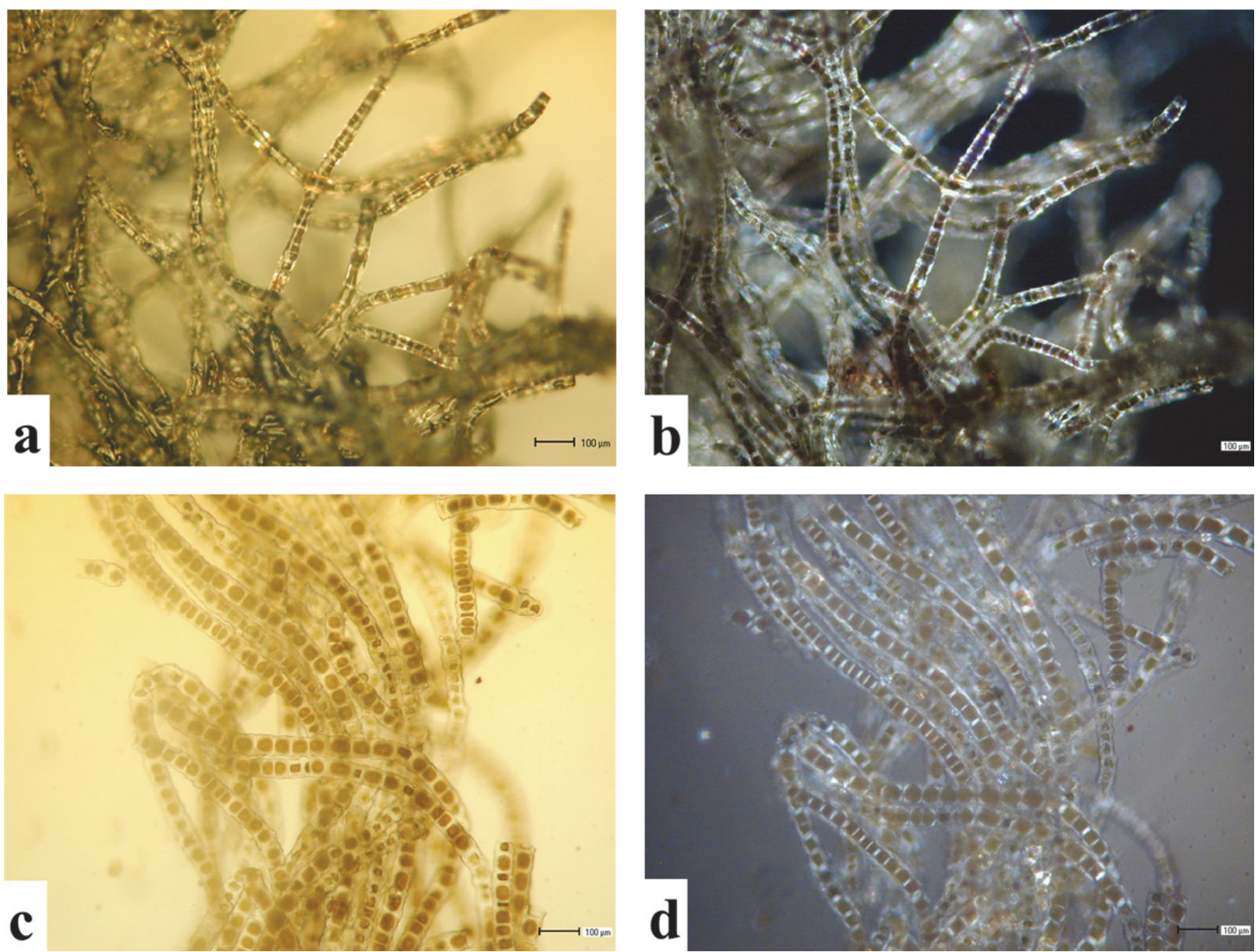

Fig. 5. The green alga of the genus Zygogonium spec.: a) air dry, light microscopy; b) air dry, polarizing microscopy; c) wet, light microscopy; d) wet, polarizing microscopy.

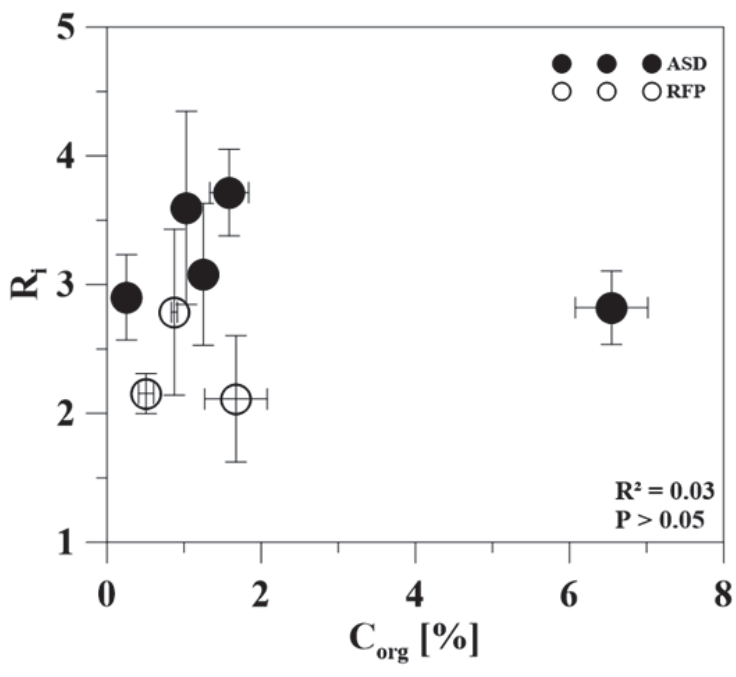

Fig. 6. Correlation between mean organic carbon $\left(\mathrm{C}_{\text {org }}, n=2\right)$ and mean repellency index $\left(R_{i}, n=10\right)$ obtained on biological soil crust samples at different developmental stages on the study sites ASD and RFP.

on ASD and on RFP, respectively, and decreased with crust development to values below 1.6 for the mature crusts. The field capacities amounted to $11 \%$ in the mineral substrate and exceeded $20 \%$ at later stages of crust development. On RFP, $\Theta_{r}$ was continuous lower than on ASD $(\mathrm{P}<0.05)$. The correlation of $\Theta_{s}$ and the organic carbon content showed an increase of the saturated water content with increasing crustal biomass (Fig. 8). The more mature and final soil crusts were in the higher range of values. Differences between the crustal succession stages were not significant.

It should be noticed that the thalli of the lichen Cladonia glauca and the moss Ceratodon purpureus lead to the formation of an organic layer resembling that of soil humus (Fig. $2 \mathrm{c}$ and $\mathrm{d}$ ), thus resulting in some distortion of the soil core reference volume at water saturation at later stages of crust succession.

\section{DISCUSSION \\ Water repellency and infiltration}

Due to pore clogging by cross-linking of sand particles with green algal filaments (Fischer et al., 2010; Lichner et al., 2013; Malam Issa et al., 2009; Spröte, 2013; Yair et al., 2008), an increase of the repellency index and reduced infiltration rates were observed with progressing crust development (Fig. 4 and 8). A larger and denser linkage between biotic and mineral components led to lower infiltration. The occurrence of Zygogonium on the soil surface led to an increase of the water repellency in Dutch coastal and inland sand dunes (Jungerius and Dekker, 1990; Pluis, 1994) and on dumped material in post-mining sites (Fischer et al., 2014), whereas decreased water repellency together with increased appearance of moss plants in more mature crusts may indicate that the changing crustal 


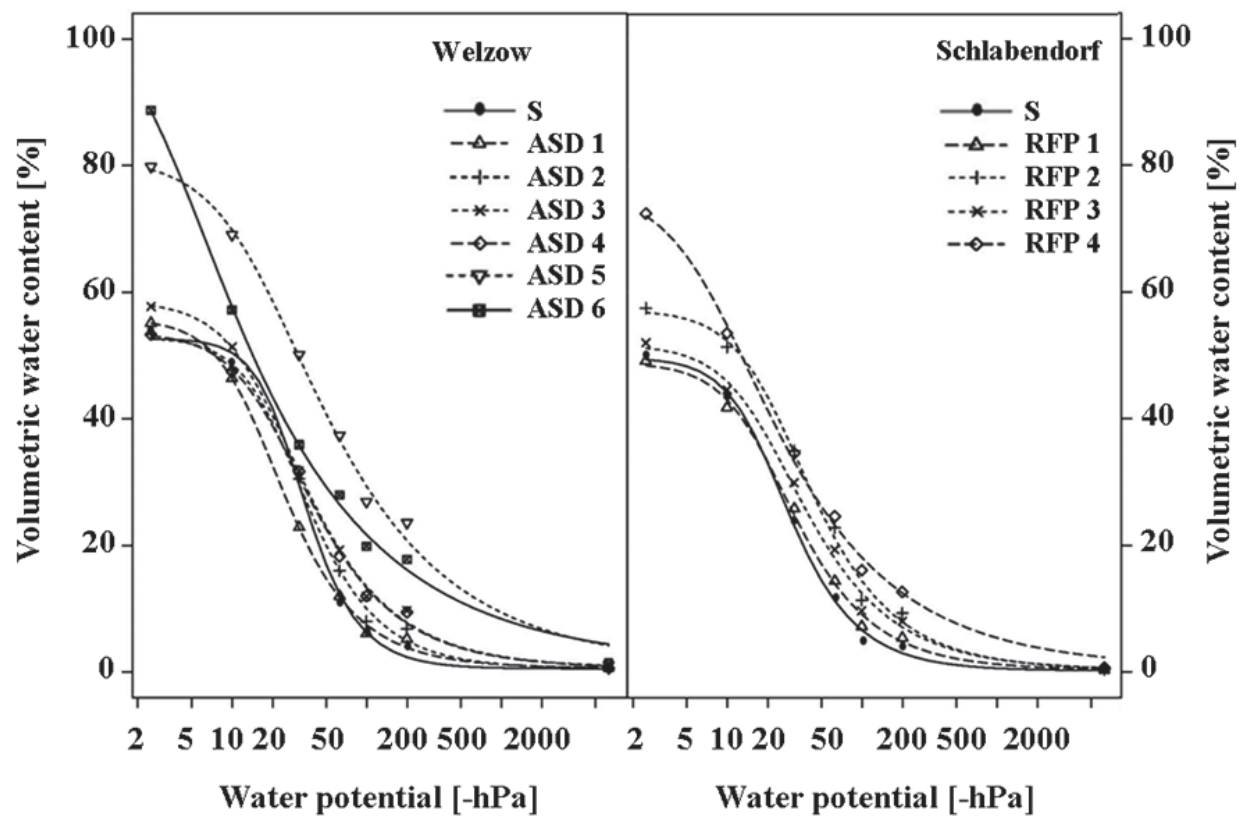

Fig. 7. pF-curves of the biological soil crust samples at different developmental stages on the study sites ASD and RFP ( $S=$ substrate).

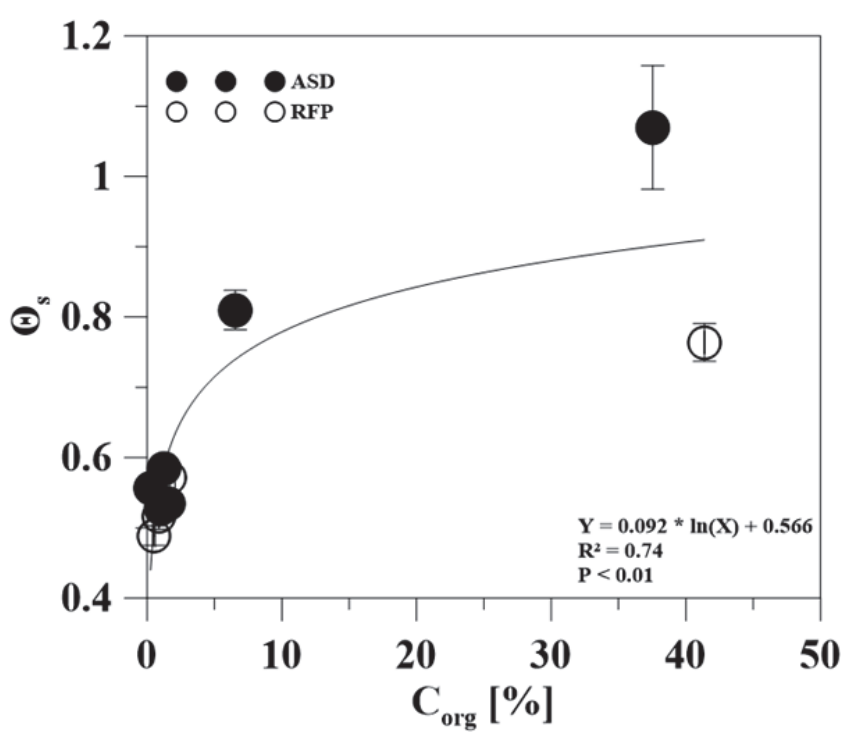

Fig. 8. Correlation between mean organic carbon $\left(\mathrm{C}_{\text {org }}, n=2\right)$ and the mean saturated water content $\left(\Theta_{s}, n=2\right)$ obtained on biological soil crust samples at different developmental stages on the study sites ASD and RFP.

species formation affected the run-off in small-scale on biocrusts. Under low rainfall intensity, mosses in biological soil crusts absorb water and reduce small-scale run-off (Yair et al., 2008), but could also inhibit infiltration to deeper soil layers (Veste et al., 2011). In our study, at later successional stages the dense linkage of soil particles by green algae decreased, but the growth of moss plants and lichen thalli increased. Hence, the dry substrate might have been aerated by rhizoid growth of mosses, and after passing a threshold of absorption capacity at $60 \mathrm{hPa}$, the moss plants could have increased infiltration along their rhizoids (Spröte, 2013; Spröte et al., 2010).

We supposed that the absent significance of correlation between $R_{i}$ and organic carbon could be attributed to the different species formation and distribution. While the occurrence of green algae resulted in an increasing $R_{i}$, the growth of mosses led to a decrease. Because of the heterogenic contribution of mosses and green algae between the crustal development stages, a correlation of the repellent behaviour with just the organic carbon was not conclusive. This could be supported by the significant difference of the $R_{i}$ between both study sites. While on the ASD a similar species composition was observed, the abundance was substantially lower than observed on the RFP. Hence, this resulted in a higher heterogeneity between the sites compared to the stages of development of each site.

Conglutination of crusts through extracellular polymeric substance excreted by algae and cyanobacteria (e.g. Chen et al., 2014; Colica et al., 2014; Fischer et al., 2010; Katznelson, 1989; Kidron et al., 1999; Malam Issa et al., 2009; Mazor et al., 1996; Rossi et al., 2012) was mentioned as one reason for the decreasing infiltration and higher water repellency. However, cyanobacteria always dominated the crusts studied there. Hoppert et al. (2004) and Mazor et al. (1996) determined EPS in cultures with cyanobacteria by using electron and light microscopy. In the present study, we found the green algae Zygogonium spec., a small proportion of Ulothrix spec., but no cyanobacteria. For an optimal growth of cyanobacteria, the soil $\mathrm{pH}$ should be slightly alkaline or neutral (Belnap and Lange, 2003; Rosentreter and Belnap, 2003), while on ASD the pH ranged from 5.1 to 5.6 and on RFP from 4.9 to 5.7 (Gypser et al., 2015). Under acidic soil conditions and $\mathrm{pH}$ values below 5 or 4 these organisms were normally absent (Brock, 1973) and more eukaryotic green algae appear (Lukešová, 2001). Due to this reason, we isolated green algal filaments of Zygogonium spec. and analysed them while dry, during and after wetting by light and polarizing microscopy, but no EPS excretion was observed (Fig. 5). We confirmed the findings of Hoppert et al. (2004), who did not discover polysaccharide encapsulation or mucilaginous cover in the green algal genus Zygogonium.

Furthermore, the ground vegetation, but also the growth of pines as pioneer trees on nutrient poor sandy soils, may have affected the repellent behaviour of soils. Due to hydrophobic 
compounds from the organic matter of, for example, needles of Pinus sylvestris, high levels of repellency occurred in sandy soils, especially in the topsoil layers (Buczko and Bens, 2006; Buczko et al., 2005, 2007; Spröte et al. 2011). Buczko et al. (2002) found a positive correlation between WDPT-measured repellency and the soil organic matter $(\mathrm{R}>0.05)$ under pine trees. In our study, Pinus sylvestris grew on both study sites, but because of the distance to the soil crust samples, a direct influence was only possible on sample ASD 6, which was excluded from repellency measurements. Hence, this factor influencing infiltration could not be verified.

The ethanol-water method proposed by Hallett and Young (1999) used the different infiltration of water and ethanol at a given pressure head, proposing that the infiltration of ethanol was not influenced by non-polar (or better low-energy) surfaces, but water was, due to its high polarity. The repellency index corrects differences in viscosity in a way that totally nonrepellent soil has a value of 1 . Following the definition by Hallet and Young (1999) the biocrusts and the substrate were water repellent $\left(R_{i}>1\right)$. However, in the traditional sense of possessing supercritical contact angles with water drops persisting on the surface, the biocrusts are non-hydrophobic. Traditionally, such supercritical repellency is addressed using contact angles and water drop penetration time (WDPT-test). It was our assumption that water repellency does not appear instantly in non-repellent surfaces, but that it develops over time reaching some threshold value which can be determined using contact angles or WDPT. We used the repellency index to characterize the development of hydrophobicity before reaching this threshold. Therefore, the repellency index should probably be regarded as "subcritical soil hydrophobicity", as proposed by Hallett et al. (2001).

\section{Water retention}

It was demonstrated that the water holding capacity (WHC) increased with the accumulation of green algal biomass (Fischer et al., 2012; Warren, 2003). The different binding strength and water retention may be due to an increase of the adsorbent surface and a decrease of the pore diameter (Malam Issa et al., 2009), because of the cross-linking of sand particles by the green alga Zygogonium spec. The decreasing porerelated van Genuchten parameter $n$ (Table 1 ) indicates a claylike behaviour of the developed biocrusts. Via capillarity of the constricted pores, the soil crusts exerted a higher moisture tension, which increased with decreasing water content (Blume et al., 2010). The individual crust organisms absorbed water as well (Belnap, 2006), especially due to the higher volume through distinctive moss-lichen crusts. Because of these reasons, the $\mathrm{pF}$-curves changed from the pure sandy substrate to a clay-like curse, similar to $n$. However, a sudden decline of the $\Theta_{s}$ was measured in crust sample RFP 3. Due to the texture of the substrate, which did not differ significantly between the study sites ASD and RFP, an influence of the mineral substrate was excluded. Certainly, a large cover of the crustose lichen Placynthiella oligotropha was observed. We assumed that this crustose lichen clogged pores and sealed the crust surface, resulting in a decrease of the infiltration rate (Eldridge et al., 2010; Warren, 2003). Differently from pore clogging by green algae, the lichen grew more crustose and adhered directly to the soil particles, hence, not only pores were clogged, but the crust surface was also sealed. Furthermore, increasing surface coverage and thickness presumably lead to prolonged water retention after wetting.
The saturated water content $\Theta_{s}$ was highest in crust sample ASD 5 and amounted to $81 \%$. Presumably, this might be explained by the formation of a Zygogonium spec. dominated the soil crust, which was thicker, compared to other soil crusts. When dry, the crust ASD 5 could be lifted off the soil as thick substrate-algal layer and could adsorb more water to the large inner crust surface as well as absorb by swelling (Belnap, 2006). In contrast, the saturated water content of $\Theta_{s}$ of ASD 4 did not differ remarkably from that of ASD 1 and was only slightly higher than that of the substrate (Table 1). While the soil lichens grew mainly at the crust surface, most mosses grew into the algal layer, thereby hydrologically connecting the upper crust with the subjacent substrate. Further, green algae formed small-scale carpets in crust ASD 4, which were slightly thicker than in the less mature crusts. Hence, the saturated water content decreased, but the water retention time increased due to the water absorption of green algae and mosses (Belnap, 2006). Compared to the sample ASD $1, \Theta_{s}$ was lower in crust ASD 2. This was likely due to changes in the pore structure, as we observed formation of voids by shrinking of ASD 1 during dehydration on the sand bed.

The distortion of the soil core reference volume by mosses and lichens at later stages of crust succession, resulted in higher $\Theta_{s}$, as mentioned, and it could be concluded that the additional moisture was absorbed by the lichen thalli and moss plants. Also, the residual water content was slightly higher, while the pF-curves showed a faster drainage compared to soil crusts with less distinctive mosses and lichens. That led to the conclusion that moss carpets and fruticose soil lichens were able to affect the water retention as well, but less strong than the crosslinking of soil particles by algae filaments did.

Due to the of the inhomogeneous distribution of lichens and mosses as well as the varying thickness of Zygogonium layers, the water retention differed between the study sites and between samples of similar developmental stages. Via water absorption by soil organisms and adsorption on organic matter, biological soil crusts were able to reduce run-off, store and redistribute water for promoting the growth of higher plants (Belnap, 2006). Hence, they were able to raise the length of availability of plant available soil water reserves (Bowker, 2007). On the other hand, investigations showed a promoted run-off by soil crusts (e.g. Kidron et al., 1999; Malam Issa et al., 2009). Run-off generation on soils with biological soil crusts was also caused by hydrophobic polymers and extracelluar secretions (Fischer et al., 2013), which reduced the size of pores formed by cyanobacteria (Mazor et al., 1996; Verrecchia et al., 1995) and induced run-off (Malam Issa et al., 2009). Especially green algae absorbed water and swelled after wetting, but an influence of exopolymers was not confirmed in this study, this factor of run-off generation could not be verified. Furthermore, mosses absorb water after lower amounts of rainfall and prevent small-scale run-off.

Sealing of the soil surface did not only have an effect on soil hydrological processes, but also on the establishment and germination of higher plants in temperate sand dunes (Steinlein and Wittland, 2006). However, it is still unclear if the surface sealing also affected run-off and re-distribution of the water along the slope and the soil water availability for higher plants under the temperate climatic conditions as it was demonstrated for arid dunes (Veste, 2008; Yair, 2008). In RFP it might be that a more homogeneous and small-scale water re-distribution happened due to the more planar area as it was demonstrated by Kidron (2014) for a flat area in arid dunes. 


\section{CONCLUSION}

Our study emphasised the influence of changing successional stages and species composition of biological soil crusts from initial scattered green algae crusts to distinctive moss-lichen crusts in temperate climate. During this succession, the repellency increased and infiltration rates decreased from pure substrate to green algae dominated crusts. This behaviour was caused by clogging of pores due to the cross-linking of sand particles by the filamentous green algae Zygogonium spec. In our case, the influence of EPS excreted by cyanobacteria was excluded because of the absence cyanobacteria, whereas studies carried out in arid and semiarid regions emphasised these importance on biocrusts repellency. The influence of Zygogonium spec. is still under discussion. The absorption capacity of soil crust biota as well as a decreased pore diameter in the green algae layers positively affected the water retention of crusted soil compared to pure substrate. The occurrence of moss plants with later succession weakened the repellent behaviour of the soil crusts, increased infiltration, and might have affected the run-off at small-scale on biocrusts. Certainly, the biological soil crusts showed water repellent properties but no distinctive hydrophobic characteristics. Based on the decreased repellency indices and higher water holding capacities, mature soil crusts might have reduced small-scale run-off on the crust under low rainfall intensities. On both locations, similar trends of waterrepellent behaviour and water retention related to crustal formation were observed, in spite of different relief, reclamation time and inhomogeneous distribution of crustal organisms.

The occurrence of biological soil crusts in temperate regions after disturbances should be carefully attended regarding the following reclamation measures. During their small-scale succession, biocrusts promoted soil and ecosystem development and established a basis for further growth of vegetation.

Acknowledgements. Thanks to the Lausitzer und Mitteldeutsche Bergbau-Verwaltungsgesellschaft mbH (Senftenberg, Germany) and the Vattenfall Europe Mining AG (Cottbus, Germany) for providing access to the investigation areas. We thank Diana Maria Seseerman (Cottbus) for improving the language of this article, and Dr. Giora Kidron (Jerusalem) as well as two anonymous reviewers for their helpful suggestions.

\section{REFERENCES}

Belnap, J., 2006. The potential roles of biological soil crusts in dryland hydrologic cycles. Hydrol. Process, 20, 15, 31593178.

Belnap, J., Lange, O.L., (Eds.), 2003. Biological Soil Crusts: Structure, Function and Management. Ecological Studies 150. 2nd ed. Springer, Heidelberg.

Blume, H.-P., Brümmer, G.W., Horn, R., Kandeler, E., KögelKnabner, I., Kretzschmar, R., Stahr, K., Wilke, B.M., Thiele-Bruhn, S., Welp, G., 2010. Scheffer/Schachtschabel Lehrbuch der Bodenkunde. [Textbook of soil science]. Revised 16th printing. Spektrum, Heidelberg. (In German.)

Bowker, M.A., 2007. Biological soil crust rehabilitation in theory and practice: an underexploited opportunity. Restor. Ecol., 15, 1, 13-23.

Bowker, M.A., Maestre, F.T., Eldridge, D., Belnap, J., CastilloMonroy, A., Escolarm C., Soliveres, S., 2014. Biological soil crusts (biocrusts) as a model system in community, landscape and ecosystem ecology. Biodivers. Conserv., 23, 1619-1637.
Bradshaw, A., 1997. Resoration of mined lands - using natural processes. Ecol. Eng., 8, 255-269.

Breckle, S.-W, Yair, A., Veste, M. (Eds.). 2008. Arid Dune Ecosystems - The Nizzana Sands in the Negev Desert, Ecol. Stud., No. 200, Springer, Berlin Heidelberg New York.

Brevik, E.C., Cerdà, A., Mataix-Solera, J., Pereg, L., Quinton, J.N., Six, J., Van Oosten, K., 2015. The interdisciplinary nature of SOIL. Soil, 1, 117-129.

Brock, T.D., 1973. Lower pH limit for the existence of bluegreen algae: evolutionary and ecological implications. Science, 179, 4072, 480-483.

Buczko, U., Bens, O., 2006. Assessing soil hydrophobicity and its variability through the soil profile using two different methods. Soil Sci. Soc. Am. J., 70, 718-727.

Buczko, U., Bens, O., Fischer, H., Hüttl, R.F., 2002. Water repellency in sandy luvisols under different forest transformation stages in northeast Germany. Geoderma, 109, $1-18$.

Buczko, U., Bens, O., Hüttl, R.F., 2005. Variability of soil water repellency in sandy forest soils with different stand structure under scots pine (Pinus sylvestris) and beech (Fagus sylvatica). Geoderma, 126, 317-336.

Buczko, U., Bens, O., Hüttl, R.F., 2007. Changes in soil water repellency in a pine-beech forest transformation chronosequence: influence of antecedent rainfall and air temperatures. Ecol. Eng., 31, 154-164.

Büdel, B., 2003. Biological soil crusts of european temperate and mediterranean regions. In: Belnap, J., Lange, O.L. (Eds.): Biological Soil Crusts: Structure, Function and Management. Ecol. Stud., No. 150, Revised 2nd. printing, Springer, Berlin, Heidelberg, pp. 75-86.

Büdel, B., Veste, M., 2008. Biological crusts. In: Breckle, S.W, Yair, A., Veste, M. (Eds.): Arid Dune Ecosystems - The Nizzana Sands in the Negev Desert, Ecological Studies 200, Springer, Berlin Heidelberg New York, pp. 149-155.

Chen, L., Rossi, F., Deng, S., Liu, Y., Wang, G., Adessi, A., De Philippis, R., 2014. Macromolecular and chemical features of excreted extracellular polysaccharides in induced biological soil crusts of different ages. Soil Biol. Biochem., 78, 1-9.

Colica, G., Li, H., Rossi, F., Li, D., Liu, Y., De Philippis, R., 2014. Microbial secreted exopolysaccharides affect the hydrological behavior of induced biological soil crusts in desert sandy soils. Soil Biol. Biochem., 68, 62-70.

Cooke, J.A., 1999. Mining. In: Walker, L.R. (Ed.): ecosystems of disturbed ground, Ecosystems of the World. 16th ed., Elsevier, Amsterdam, pp. 365-384.

Cutler, N.A., Belyea, L.R., Dugmore, A.J., 2008. The spatiotemporal dynamics of a primary succession. J. Ecol. 96, 231-246.

Deutscher Wetterdienst, Bundesministerium für Verkehr und digitale Infrastruktur online, 2014. Mittelwerte 30-jähriger Perioden. Mittelwerte für den aktuellen Stationsstandort (2012) für den Zeitraum 1981-2010. [Average of 30 years period. Average for the current station site (2012) for the period 1981-2012].

URL:http://www.dwd.de/bvbw/appmanager/bvbw/dwdwww Desktop?_nfpb=true\&_pageLabel=dwdwww_menu2_presse \&T98029gsbDocumentPath=Navigation $\% 2$ FPresse $\% 2$ FKlim ainformationen $\% 2$ Fbeschreibung_mittelwerte_node.html $\%$ $3 \mathrm{~F} \_\mathrm{nnn} \% 3 \mathrm{Dtrue}$, [28.04.2014].

Dümig, A., Veste, M., Hagedorn, F., Fischer, T., Lange, P., Spröte, R., Kögel-Knabner, I., 2013. Biological soil crusts on initial soils: organic carbon dynamics and chemistry 
under temperate climatic conditions. Biogeosciences Discuss., 10, 851-894.

Dümig, A., Veste, M., Hagedorn, F., Fischer, T., Lange, P., Spröte, R., Kögel-Knabner, I., 2014. Organic matter from biological soil crusts induces the initial formation of sandy temperate soils. Catena, 122, 196-208.

Dutta, S., Rajaram, R., Robinson, B., 2005. Mineland reclamation. In: Rajaram, V., Dutta, S., Parameswaran, K. (Ed.): Sustainable Mining Practices - A Global Perspective. Taylor \& Francis, Leiden, pp. 179-191.

Eldridge, D.J., Zaady, E., Shachack, M., 2002. Microphytic crusts, shrub patches, and water harvesting in the Negev desert: the Shikim system. Landscape Ecol., 17, 6, 587-597.

Eldridge, D.J., Bowker, M.A., Maestre, F.T., Alonso, P., Mau, R.L., Papadopoulos, J., Escudero, A., 2010. Interactive effects of three ecosystem engineers on infiltration in a semiarid mediterranean grassland. Ecosystems, 13, 499-510.

Elliott, E.T., 1985. Aggregate structure and carbon, nitrogen, and phosphorus in native and cultivated soils. Soil Sci. Soc. Am. J., 50, 627-633.

Fischer, T., Veste, M., Wiehe, W., Lange, P., 2010. Water repellency and pore clogging at early successional stages of microbiotic crusts on inland dunes, Brandenburg, NE Germany. Catena, 80, 1, 47-52.

Fischer, T., Yair, A., Veste, M., 2012. Microstructure and hydraulic properties of biological soil crusts on sand dunes: a comparison between arid and temperate climates. Biogeosciences Discuss., 9, 12711-12734.

Fischer, T., Yair, A., Veste, M., Geppert, H., 2013. Hydraulic properties of biological soil crusts on sand dunes studied by ${ }^{13} \mathrm{C}-\mathrm{CP} / \mathrm{MAS}-\mathrm{NMR}$ : A comparison between an arid and a temperate site. Catena, 110, 155-160.

Fischer, T., Gypser, S., Subbotina, M., Veste, M., 2014. Synergic hydraulic and nutritional feedback mechanisms control surface patchiness of biological soil crusts on tertiary sands at a post-mining site. J. Hydrol. Hydromech., 62, 293302.

Gerwin, W., Raab, T., Biemelt, D., Bens, O., Hüttl, R.F., 2009. The artificial water catchment "Chicken Creek" as an observatory for critical zone processes and structures. Hydrol. Earth Syst. Sci. Discuss., 6, 1769-1795.

Gypser, S., Veste, M., Fischer, T., Lange, P., 2015. Formation of soil lichen crusts at reclaimed post-mining sites, Lower Lusatia, North-east Germany. Graphis Scripta, 27, 3-14.

Hallett, P.D., Young, I.M., 1999. Changes to water repellence of soil aggregates caused by substrate-induced microbial activity. Europ. J. Soil Sci., 50, 1, 35-40.

Hallett, P.D., Baumgartl T., Young, I.M., 2001. Subcritical water repellency of aggregates from a range of soil management practices. Soil Sci. Soc. Am. J., 65, 1, 184-190.

Hangen, E., Gerke, H.H., Schaaf, W., Hüttl, R.F., 2005. Assessment of preferential flow processes in a forestreclaimed lignitic mine soil by multicell sampling of drainage water and three tracers. J. Hydrol., 303, 1-4, 16-37.

Hartmann, M., 2008. Bodenphysikalische Eigenschaften, Benetzbarkeit und Wasserhaushalt von Waldböden unter Flugascheeinfluss. [Soil physical properties, wettabilities and hydrologic balance of fly ash affected forest soils]. Diss., Christian-Albrechts-Universität, Kiel. (In German.)

Hoppert, M., Reimer, R., Kemmling, A., Schröder, A., Günzl, B., Heinken, T., 2004. Structure and reactivity of a biological soil crust from a xeric sandy soil in Central Europe. Geomicrobiol. J., 21, 3, 183-191.

Housman, D.C., Powers, H.H., Collins, A.D., Belang, J., 2006. Carbon and nitrogen fixation differ between successional stags of biological soil crusts in the Colorado Plateau and Chihuahua Desert. J. Arid Environ., 66, 4, 620-634.

Hüttl, R.F., 1998. Ecology of post-mining landscapes in the Lusatian lignite mining district, Germany. In: Fox, H.R., Moore, H.M., McIntosh, A.D. (Eds.): Land reclamation achieving sustainable benefits. Balkema, Rotterdam, pp. 187-192.

International Council on Mining and Metals, 2012. Trends in the mining and metals industry. Mining's contribution to sustainable development, London.

Jungerius, P.D., Dekker, L.W., 1990. Water erosion in the dunes. In: Bakker, T.W.M., Jungerius, P.D., Klijn, J.A. (Ed.): Dunes of the European Coasts. Catena Supplement 18, pp. 185-194.

Katznelson, R., 1989. Clogging of groundwater recharge basins by cyanobacterial mats. FEMS Microb. Ecol., 62, 4, 231242.

Kidron, G., 2014. Sink plot for runoff measurements on semiflat terrains: preliminary data and their potential hydrological and ecological implications. J. Hydrol. Hydromech., 62, 4, 303-308.

Kidron, G.J., Yair, A., 1997. Rainfall-runoff relationship over encrusted dune surfaces, Nizzana, Western Negev, Israel. earth Surf. Processes, 22, 1169-1184.

Kidron, G., Yaalon, D.H., Vonshak, A., 1999. Two causes for runoff initiation on microbiotic crusts: hydrophobicity and pore clogging. Soil Sci., 164, 1, 18-27.

Kidron, G.J., Yair, A., Vonshak, A., Abeliovich, A., 2003. Microbiotic crust control runoff generation on sand dunes in the Negev Desert. Water Resour. Res., 39, 4, 1-5.

Krümmelbein, J., Horn, R., Raab, T., Bens, O., Hüttl, R.F., 2010. Soil physical parameters of a recently established agricultural recultivation site after brown coal mining in Eastern Germany. Soil Till. Res., 111, 19-25.

Krümmelbein, J., Bens, O., Raab, T., Naeth, M.A., 2012. A history of lignite coal mining and reclamation practices in Lusatia, eastern Germany. Can. J. Soil Sci., 92, 53-66.

Lambers, H., Raven, J.A., Shaver, G.R., Smith, S.E., 2008. Plant nutrient-acquisition strategies change with soil age. Trends Ecol. Evol., 23, 95-103.

Lichner, L., Hallett, P.D., Drongová, Z., Czachor, H., Kovacik, L., Mataix-Solera, J., Homolák M., 2013. Algae influence the hydrophysical parameters of a sandy soil. Catena, 108, $58-68$.

Lukešová, A., 2001. Soil algae in brown coal and lignite postmining areas in Central Europe (Czech Republic and Germany). Restor. Ecol., 9, 4, 341-350.

Mager, D.M., Thomas, A.D., 2011. Extracellular polysaccharides from cyanobacterial soil crusts: a review of their role in dryland soil processes. J. Arid Environ., 75, 2, 91-97.

Malam Issa, O., Défarge, C., Trichet, J., Valentin, C., Rajot, J.L., 2009. Microbiotic soil crusts in the Sahel of Western Niger and their influence on soil porosity and water dynamics. Catena, 77, 1, 48-55.

Mazor, G., Kidron, G.J., Vonshak, A., Abeliovich, A., 1996. The role of cyanobacterial exopolysaccharides in structuring desert microbial crusts. FEMS Microb. Ecol., 21, 2, 121-130.

Menon, M., Yuan, Q., Jia, X., Dougill, A.J., Hoon, S.R., Thomas, A.D., Williams, R.A., 2011. Assessment of physical and hydrological properties of biological soil crusts using X-ray microtomography and modeling. J. Hydrol., 397, $1-2,47-54$.

Nordstrom, D.K., Alpers, C.N., 1999. Negative pH, efflorescent mineralogy, and consequences for environmental restoration 
at the Iron Mountain Superfund site, California. Proc. Natl. Acad. Sci. USA 96, 3455-3463.

Passioura, J.B., 1991. Soil structure and plant growth. Aust. J. Soil Res., 29, 717-728.

Pluis, J.L.A., 1994. Algal crust formation in the inland dune area, Laarder Wasmeer, the Netherlands. Vegetatio, 113, 41-51.

Reuter, R., 1997. Sewage sludge as an organic amendment for reclaiming surface mine wastes. Restoration and Reclamation Review, 2, 7, 1-6.

Roberts, J.A., Daniels, W.L., Burger, J.A., Bell, J.C., 1988. Early Stages of Mine Soil Genesis in a Southwest Virginia Spoil Lithosequence. Soil Sci. Soc. Am. J., 52, 3, 716-723.

Rosentreter, R., Belnap, J., 2003. Biological soil crusts of North America. In: Belnap, J., Lange, O.L. (Eds.): Biological Soil Crusts: Structure, Function and Management. Ecol. Stud., No. 150, Revised 2nd. printing, Springer, Berlin, Heidelberg, pp. 31-50.

Rossi, F., Potrafka, R.M., Pichel, F.G., De Philippis, R., 2012. The role of the exopolysaccharides in enhancing hydraulic conductivity of biological soil crusts. Soil Biol. Biochem., $46,33-40$.

Schaaf, W., Hüttl., R.F., 2005. Soil chemistry and tree nutrition of post-lignite-mining sites. J. Plant Nutr. Soil Sci., 168, 4, 483-488.

Šourková, M., Frouz, J., Fettweis, U., Bens, O., Hüttl, R.F., Šantrůčková, H., 2005. Soil development and properties of microbial biomass succession in reclaimed post mining sites near Sokolov (Czech Republic) and near Cottbus (Germany). Geoderma, 129, 1-2, 73-80.

Spröte, R., 2013. Entwicklung von Benetzungshemmung auf sandigen Substraten unter dem Einfluss biologischer Bodenkrusten und höherer Vegetationsentwicklung. [Development of repellency on sandy substrate influenced by biological soil crusts and development of higher vegetation]. Diss. Cottbuser Schriften zu Bodenschutz und Rekultivierung, No. 44, Brandenburgische Technische Universität, Cottbus. (In German.)

Spröte, R., Fischer, T., Veste, M., Raab, T., Wiehe, W., Lange, P., Bens, O., Hüttl, R.F., 2010. Biological topsoil crusts at early successional stages on Quaternary substrates dumped by mining in Brandenburg, NE Germany. Géomorphologie, 4, 359-370.

Spröte, R., Veste, M., Fischer, T., Lange, P., Bens, O., Raab, T., Hüttl, R.F., 2011. Wie beeinflussen Kiefern (Pinus sylvestris L.) die Entwicklung der Benetzungshemmung auf Sandböden? [How does Pinus sylvestrius (L.) affect the development of repellency on sandy soils?]. In: Jahrestagung der deutschen Bodenkundlichen Gesellschaft 2011, Berlin. (In German.)

Statistik der Kohlewirtschaft e.V., 2013. Braunkohleförderung nach Ländern ab 2000. [Lignite mining sorted by country from 2000]. URL http://www.kohlenstatistik.de/16-0International.html, Cologne.

Steinlein, T., Wittland, M., 2006. The role of soil seed bank, germination ecology and the influence of soil crusts for the successful establishment of dominant plant species on sandy soils. In: Jiarong, G., Veste, M., Beyschlag, W. (Eds.): Restoration and stability of ecosystems in arid and semi-arid areas. Science Press, Beijing, pp. 65-76.
Stewart, K.J., Siciliano, S.D., 2015. Potential contribution of native herbs and biological soil crusts to restoration of the biogeochemical nitrogen cycle in mining impacted sites in Northern Canada. Ecol. Restor., 33, 30-42.

Verrecchia, E., Yair, A., Kidron, G.J., Verrecchia, K., 1995. Physical properties of the psammophile cryptogamic crust and their consequences to the water regime of sandy soils, north-western Negev desert, Israel. J. Arid Environ., 29, 4, 427-437.

Veste, M., 2005. Importance of biological soil crusts for rehabilitation of degraded arid and semi-arid ecosystems. Sci. Soil Water Conserv., 3, 4, 42-47.

Veste, M., 2008. Spatial and temporal variation of the plant water status and gas exchange. In: Breckle, S.-W, Yair, A., Veste, M. (Eds.): Arid Dune Ecosystems - The Nizzana Sands in the Negev Desert, Ecol. Stud., No. 200, Springer, Berlin Heidelberg New York, pp. 367-375.

Veste, M., Breckle, S.-W., Eggert, K., Littmann, T., 2011. Vegetation pattern in arid sand dunes controlled by biological soil crusts along a climatic gradient in the Northern Negev desert. Basic and Appl. Dryland Res., 5, 116.

Walker, L.R., Willig, M.R., 1999. An introduction to terrestrial disturbances. In: Walker, L.R. (Ed.): ecosystems of disturbed ground, Ecosystems of the World. 16th ed., Elsevier, Amsterdam, pp. 1-16.

Warren, S.D., 2003. Synopsis: Influence of biological soil crusts on arid land hydrology and soil stability. In: Belnap, J., Lange, O.L. (Eds.): Biological Soil Crusts: Structure, Function and Management. Ecol. Stud., No. 150, Revised 2nd. printing, Springer, Berlin, Heidelberg, pp. 349-360.

Wiegleb, G., Felinks, B., 2001. Primary succession in postmining landscapes of Lower Lusatia - chance or necessity. Ecol. Eng., 17, 2-3, 199-217.

Williams, J.D., Dobrowolski, J.P., West, N.E., 1999. Microbiotic crust influence on unsaturated hydraulic conductivity. Arid Soil Res. Rehab., 13, 2, 145-154.

Yair, A., 2008. Effects of surface runoff and subsurface flow on the spatial variability of water resources in longitudinal dunes. In: Breckle, S.-W, Yair, A., Veste, M. (Eds.): Arid Dune Ecosystems - The Nizzana Sands in the Negev Desert, Ecol. Stud., No. 200, Springer, Berlin Heidelberg New York, pp. 251-269.

Yair, A., Veste, M., Almog, R., Breckle, S.-W., 2008. Sensitivity of a Sandy Area to Climate Change Along a Rainfall Gradient at a Desert Fringe. In: Breckle, S.-W, Yair, A., Veste, M. (Eds.): Arid Dune Ecosystems - The Nizzana Sands in the Negev Desert, Ecol. Stud., No. 200, Springer, Berlin Heidelberg New York, pp. 425-440.

Yair, A., Almog, R., Veste, M., 2011. Differential hydrological response of biological topsoil crusts along a rainfall gradient in a sandy arid area: Northern Negev desert, Israel. Catena, $87,3,326-333$.

Received 6 July 2015 Accepted 12 November 2015

Note: Colour version of Figures can be found in the web version of this article. 